\title{
PENINGKATAN KESADARAN HUKUM REMAJA MELALUI DRAMA PERMAINAN
}

\author{
Habibi \\ Sekolah Tinggi Agama Hindu Negeri (STAHN) Gde Pudja Mataram, Indonesia \\ habibi59595866@gmail.com
}

\begin{abstract}
This community service activity is an effort to increase legal awareness among adolescents. Build legal awareness from an early age, do not have to wait after violations and prosecution by law enforcers. Prevention efforts are considered very important and can be started from within the family as the smallest unit of society. To increase legal awareness, understanding in the field of law is needed. Understanding in the field of law will be easy to understand if it is done with the game method (drama). As for the purpose of implementing this activity to increase legal understanding and awareness among adolescents so that it is hoped that in the future it will reduce legal violations among adolescents. The method used is the planning stage method and the implementation stage. In this community service, it is carried out with the participants playing a drama that has been composed by the service team. This drama tells about events that are often experienced, namely theft. To play this drama plays a victim, perpetrator of crime, community / youth leaders, police and judges. Youth who take part in this activity understand and understand the purpose of this activity, and Youth can master the material that has been given by the implementation team
\end{abstract}

Keywords: adolescents, legal awareness

\begin{abstract}
Abstrak
Kegiatan pengabdian masyarakat ini sebagai salah satu upaya meningkatkan kesadaran hukum dikalangan remaja. Membangun kesadaran hukum sejak dini, tidak harus menunggu setelah terjadi pelanggaran dan penindakan oleh penegak hukum. Upaya pencegahan dinilai sangat penting dan bisa dimulai dari dalam keluarga sebagai unit terkecil masyarakat Untuk meningkatkan kesadaran hukum diperlukan pemahaman dibidang hukum. Pemahaman dibidang hukum akan mudah dipahami apabila dilakukan dengan metode permainan (drama). Adapaun tujuan pelaksanaan kegiatan ini untuk meningkatkan pemahaman dan kesadaran hukum dikalangan remaja sehingga diharapkan kedepannya mengurangi pelanggaran hukum dikalangan remaja. Metode yang dilakukan yakni dengan metode tahap perencanaan dan tahap pelaksanaan. Dalam pengabdian masyarakat ini dilakukan dengan pesertanya yang memainkan drama yang telah disusun oleh tim pengabdian. Drama ini menceritakan tentang kejadian yang sering dialami yakni pencurian. Untuk memerankan drama ini memerankan sebagai korban, pelaku kejahatan, tokoh masyarakat/pemuda, polisi dan hakim. Remaja yang mengikuti kegiatan ini memahami dan mengerti tujuan dari kegiatan ini, dan Remaja dapat menguasai materi yang telah diberikan tim pelaksana.
\end{abstract}

Kata Kunci: remaja, kesadaran hukum.

Submitted: $2020-08-30$ Revised: 2020-09-12 Accepted: $2020-09-15$

\section{Pendahuluan}

Istilah kesadaran hukum sering didengungkan baik oleh pemerintah dan masyarakat karena terkait dengan pola prilaku seseorang dalam berinterkasi dengan yang lainnya. Menurut Soerjono Soekanto (2002:215) Kesadaran Hukum adalah persoalan nilai nilai yang terdapat pada diri manusia tentang hukum yang ada atau tentang hukum yang diharapkan ada. Minimnya kesadaran hukum di suatu wilayah akan memunculkan 
masyarakat yang kurang sadar akan hukum. Membangun kesadaran hukum sejak dini, tidak harus menunggu setelah terjadi pelanggaran dan penindakan oleh penegak hukum. Upaya pencegahan dinilai sangat penting dan bisa dimulai dari dalam keluarga sebagai unit terkecil masyarakat. Dengan adanya kesadaran hukum ini kita akan menyaksikan tidak adanya pelanggaran sehingga kehidupan yang ideal akan ditemui.

Lembaga pendidikan formal, informal dan non formal perlu diajak bersama-sama mengembangkan kesadaran dan kecerdasan hukum sejak dini. Pendidikan hukum tidak terbatas hanya pendidikan formal di bangku sekolah saja. Namun juga dapat dilakukan di luar bangku sekolah. Pembelajaran mengenai hukum sejak dini harus diajarkan kepada anak-anak. Agar nantinya tertanam dalam diri mereka rasa kebutuhan akan peraturan hukum. Sehingga kesadaran hukum akan terbentuk sejak dini.

Upaya mengenalkan hukum secara benar kepada remaja ternyata tidak mudah. Karena masa remaja merupakan masa peralihan dari anak anak kedewasa yang ditandai dengan perubahan fisik, emosi dan psikis (Widyastuti Dkk,2009:2). Sehingga Tantangan itu muncul untuk memperkenalkan kesadaran hukum mengingat sifat ilmu hukum yang sui generis, atau sesuatu yang khas dan arus dipelajari sebagai ilmu tersendiri, belum lagi sifat hukum yang selalu berubah dan semakin kompleks. Jangankan ayah-bunda atau pendidik yang tidak mengenyam pendidikan hukum, mereka yang berkecimpung di bidang hukum sekalipun sepintas lalu akan merasa tidak mampu mengenalkan hukum kepada anak karena kompleksitasnya.(https://www.childrencafe.com/bagaimanamengenalkan-hukum-pada-anak/)

Menghadapi berbagai kerumitan hukum yang menghambat pembelajaran kita terhadap hukum yang berjalan menghambat upaya pengenalan hukum pada anak itu selayaknya tidak membuat kita putus asa. Untuk memulai upaya mengenalkan hukum pada anak memang membutuhkan upaya ekstra khususnya orang tua.

Mengenalkan hukum tidak sama dengan mengenal undang-undang. Anak-anak apalagi usia dini tidak selayaknya dikenalkan dengan pasal-pasal yang bahkan memusingkan bagi orang dewasa. Kenalkan hukum kepada anak melaluisikapkitaterhadapkejadiansehari-hari di rumah. Misalnya, apabila siadik bertengkar dengan kakak, jangan buru-buru marah atau menegur tanpa terlebih dahulu kita bertanya kepada keduanya.

Pengenalan hukum untuk anak sekolah dasar bisa diterapkan melalui berbagai cara, bisa melalui aktivitas fisik yang ringan. Aktivitas fisik dalam pengenalan hukum bisa juga diterapkan melalui permain yang berhubungan dengan aktivitas fisik. Dimasaanakanak dapat dikatakan mereka lebih suka bermain dari pada belajar. Belajarpun mereka sambal bermain. Tidak ada beban bagi mereka, sehingga mereka akan bermain sampai mereka merasa lelah dan kontor. Walaupun sesekali menangis, ia akan kembali tertawa riang. Baru saja sebentar bertengkar dengan teman, sudah kembali berbaikan. Begitulah anak kecil. Menurut Santrock (2002: 273) permainan (play) adalah suatu kegiatan menyenangkan yang dilaksanakan untuk kepentingan kegiatan itu sendiri kegiatan tersebut dilakukan tanpa paksaan dan dengan perasaan senang. Sebuah permainan terdapat peraturan yang bertujuan untuk membatasi perilaku pemain dan menentukan permainan. Permainan bertujuan untuk menghibur dan banyak disukai oleh anak-anak hingga orang dewasa (Moeslichatoen, 2004: 24). 
Permainan yang bisa dimainkan untuk mengenal hukum peserta adalah permainan maling-malingan. Permainan ini menggambarkan bagaimana peran polisi yang menangkap maling dan bagaimana peran warga masyarakat untuk tidak menghakimi seseorang yang melakukan pencurian. Tiga fungsi permainan yaitu fungsi kognitif, fungsi sosial dan fungsi emosi. Melalui permainan memungkinkan anak-anak mengembangkan kompetensi-kompetensi dan keterampilan-keterampilan yang diperlukan dengan cara yang menyenangkan.( Nesna Agustriana, 2013:2)

\section{Metode}

Sasaran pada kegiatan ini adalah remaja siswa SD atau SMP pada Banjar Tegeh dusun Kerandangan Desa senggigi kecamatan batu layar kabupaten Lombok barat. Metode pelaksanaan kegiatan pengabdian pada masyarakat dibagi menjadi 2 tahap, diantaranya:

\section{Tahap Perencanaan}

Tim Pelaksana pengabdian masyarakat melakukan kunjungan awal dilokasi tempat yang dilakukan pengabdian dan melakukan jumlah pendaatan remaja yang ada pada wilayah tersebut. Selanjutnya izin kegitan dilakukan dengan dengan ketua banjar. Tim pengabdian menyiapkan materi mngenai kesadaran hukum dan menyiapkan properti kegiatan.

2. Tahap pelaksanaan

Dalam tahap pelaksaanan kegiatan dibagi menjadi 3 tahap yaitu :

Tahap pertama : memberikan materi tentang pentingnya kesadaran hukum dikalangan remaja dan permasalahan yang dihadapi oleh remaja

Tahap kedua : pembentukan kelompok drama dan memainkan peran sesuai sekenario yang telah dibuat.

Tahap ketiga : setiap peserta menyampaikan kesimpulan terhadap peran yang dimainkan apakan sesuai dengan peraturan perundang.

\section{Hasil dan Pembahasan}

Kegiatan pengabdian masyarakat ini dilaksanakan pada hari kamis tanggal 21 Maret 2019 yang diikuti oleh 60 peserta yang berasal dari Banjar Tegeh Kerandangan Desa Senggigi. Pelaksanaan kegiatan pengabdian ini dilakuakan sore hingga malam hari.

Pengabdian masyarakat dillakukan dalam bentuk Penyuluhan hukum. Penyuluhan hukum biasanya dilakukan dengan metode ceramah yaitu ada penyampaian materi dan kemudian peserta bertanya terhadap materi yang telah disampaikan. Dalam pengabdian masyarakat ini dilakukan dengan pesertanya yang memainkan drama yang telah disusun oleh tim pengabdian. Drama ini menceritakan tentang kejadian yang sering dialami yakni pencurian. Untuk memerankan drama ini dtunjuk 8 orang yang memerankan sebagai korban, pelaku kejahatan, tokoh masyarakat/pemuda, polisi dan hakim. 

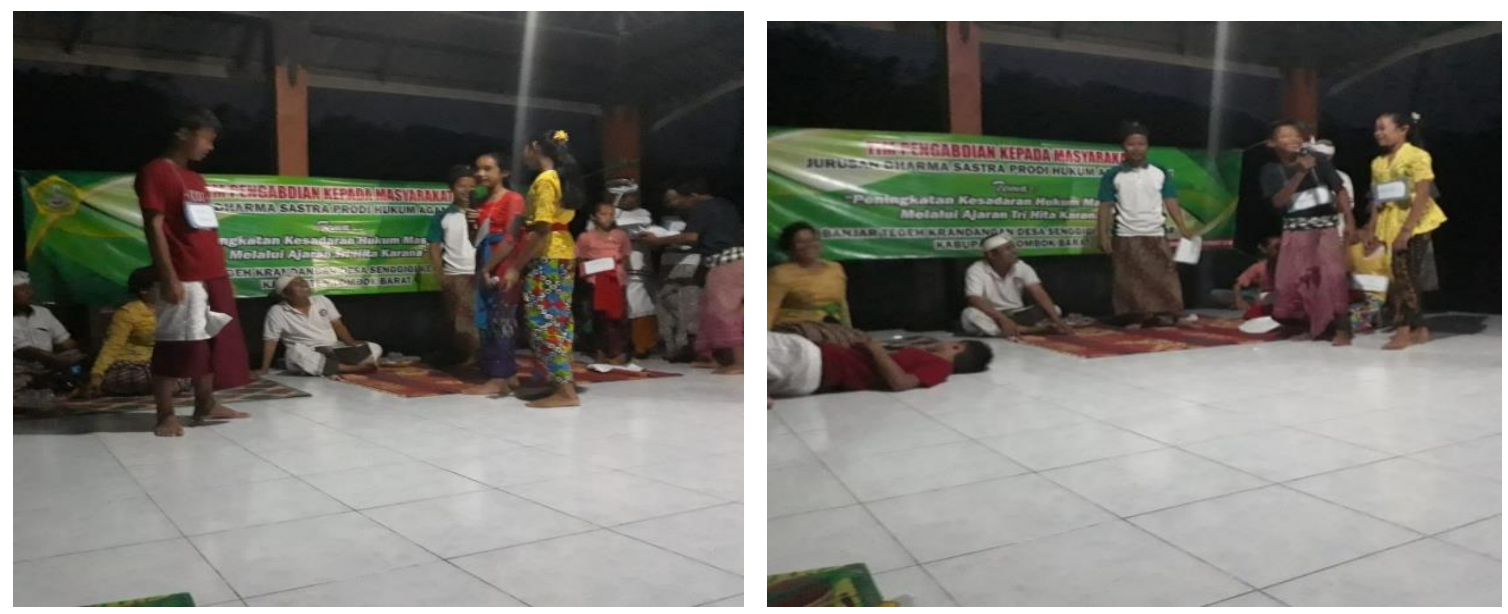

Gambar 1. Pementasan Drama Hukum

Evaluasi hasil kegiatan dalam pengabdian ini dilakukan dengan beberapa cara, hasil dilihat dari antusias remaja dalam mengikuti kegiatan ini sampai akhir acara, dan seberapa dalam mereka memahami peran yang dimainkan dalam drama hukum tersebut. Teknik evaluasi dilihat dilakukan dengan cara observasi yaitu melihat bagaimana peserta berhasil memerankan setiap adegan sesuai skenario yang telah dibuat. Rata rata peserta mampu dan memahami peran adegan tersebut dan dapat menjawab pertanyaan terkait persoalan hukum dalam kegiatan tersebut. Selama kegiatan pengabdian masyarakat dilakukan terdapat faktor faktor yang mempengaruhi pelaksanaan pengabdian. Adapun faktor pendukungnya yaitu masayarakat setempat sangat antusias dengan informasi karena baru pertama kali dilaksanakan kegiatan penyuluhan hukum, sedangkan faktor penghambatnya yaitu kurangnya sarana dan prasarana pendukung dan waktu pelaksanaan yang dirasa cukup singkat karena dilaksanakan pada malam hari.

\section{Kesimpulan}

Kegiatan Pengabdian kepada masyarakat di banjar Tegeh Kerandangan Desa senggigi berjalan dengan baik dan lancar sesuai dengan agenda rencana yang telah dibuat. Remaja yang mengikuti kegiatan ini memahami dan mengerti tujuan dari kegiatan ini, dan Remaja dapat menguasai materi yang telah diberikan tim pelaksana. Kegiatan Pengabdian ini disambut baik oleh warga yang bersemangat mengikuti kegiatan ini yang dilihat dari antusias beberapa remaja yang bertanya mengenai materi yang disampaikan. Dengan adanya bermain peran ini diharapkan kesadaran hukum terutama generasi muda dapat mudah dipahami dan diimplementasikan dalam kehidupan sehari hari.

\section{Daftar Pustaka}

Nesna Agustriana. (2013). Pengaruh Metode Edutainment Dan Konsep Diri Terhadap Keterampilan Sosial Anak. Jurnal Pendidikan Usia Dini, 7 (2) 
Santrock, John W. (2002). Life Span Development edition 5, perkembangan masa hidup jilid 1, Jakarta : Erlangga

Soerjono Soekanto. (2002). Kesadaran Hukum dan Kepatuhan Hukum. Jakarta: Raja Grafindo Persada.

Moeslichatoen. (2004). Metode Pengajaran di Taman Kanak-kanak. PT Rineka Cipta: Jakarta.

Widyastuti, Y. Rahmawati, A. Purnamaningrum. (2009). Kesehatan Reproduksi. Yogyakarta :Fitramaya.

https://www.childrencafe.com/bagaimana-mengenalkan-hukum-pada-anak/ (akses tanggal 16 Agustus 2020) 